\title{
PENGARUH RASIO KEUANGAN DAN FAKTOR NON KEUANGAN TERHADAP PENERIMAAN OPINI AUDIT GOING CONCERN
}

\author{
Cornellie Tria Simanjuntak ${ }^{1}$ \\ Sri Rejeki Saulina Hutasoit ${ }^{2}$ \\ Eva Simamora ${ }^{3}$ \\ Keumala Hayati ${ }^{4}$
Fakultas Ekonomi Universitas Prima Indonesia (UNPRI),Medan,Indonesia ${ }^{1,2,3,4}$
Email: Cornellie0303@gmail.com¹, srirejekisaulina26@gmail.com², evasimamora@gmail.com ${ }^{3}$ keumalahayatihakim@gmail.com ${ }^{4}$

\begin{abstract}
The contribution of financial ratios in the results of the audit of financial statements does not fully explain the actual condition of the company, so this study adds non-financial factors in explaining the company's survival (Going Concern). This study analyzes empirical evidence of financial and non-financial factors on going concern audit opinion acceptance. With a total population of 141 manufacturing companies listed on the Indonesia Stock Exchange from 2016 to 2018. The sampling technique method was purposive sampling with a total of 60 samples. Methods of data analysis using logistic regression models. The results obtained from hypothesis testing are (1) leverage ratio proxied by DER, (2) audit client tenure, (3) operational shopping and (4) KAP reputation has a positive effect on going concern audit opinion acceptance which strengthens the explanation of the criteria for going concern audit opinion acceptance. concern however (5) Audit Lag, (6) liquidity is proxied by CAR, (7) Profitability is proxied by ROA, (8) the proxied activity ratio of TATO has a negative effect on acceptance of going concern audit opinion which weakens the explanation of the criteria for receiving going concern audit opinion.
\end{abstract}

Keywords: Financial Factors; Non-Financial Factors; Going Concern Auditor Opinion.

\begin{abstract}
ABSTRAK
Kontribusi rasio keuangan dalam hasil audit laporan keuangan tidak sepenuhnya menjelaskan kondisi perusahaan yang sebenarnya sehingga penelitian ini menambahkan faktor non keuangan dalam menjelaskan kelangsungan hidup perusahaan (Going Concern). Penelitian ini menganalisis bukti empiris faktor keuangan dan non keuangan terhadap penerimaan opini audit going concern. Dengan jumlah populasi sebanyak 141 perusahaan manufaktur yang terdaftar di Bursa Efek Indonesia tahun 2016-2018. Metode teknik pengambilan sampel adalah purposive sampling sebanyak 60 sampel. Metode analisis data menggunakan model regresi logistik. Hasil yang diperoleh dari pengujian hipotesis adalah (1) rasio leverage diproksikan DER, (2) audit client tenure, (3) oppinion shopping dan (4) reputasi KAP berpengaruh positif terhadap penerimaan opini audit going concern yang memperkuat penjelasan kriteria untuk penerimaan opini audit going concern akan tetapi (5) Audit Lag, (6) likuiditas diproksikan CAR, (7) profitabilitas diproksikan ROA, (8) rasio aktivitas diproksikan TATO berpengaruh negatif terhadap penerimaan opini audit going concern yang memperlemah penjelasan kriteria untuk penerimaan opini audit going concern
\end{abstract}

Kata kunci : Faktor Keuangan; Faktor Non Keuangan; Pendapat Auditor Going Concern. 


\section{PENDAHULUAN}

Setiap emiten yang telah terdaftar di Bursa Efek Indonesia (BEI) selalu memastikan usahanya berada dalam garis aman. melalui evaluasi yang dilakukan BEI bisa saja dengan waktu yang singkat dapat merubah status emiten dalam BEI. Pihak ketiga dari hal ini merupakan auditor independen sebagai penilai kelangsungan hidup entitas (going concern) yang menjelaskan ataupun meramalkan tingkat keberhasilan dari usaha emiten pada periode tertentu. Hal ini dialami perusahaan PT. Borneo Lumbung Energi \& Metal Tbk (BORN) dan PT. Bara Jaya Internasional Tbk (ATPK) yang delisting dari BEI akibat kelangsungan hidup usaha (going concern) yang bermasalah karena melibatkan pihak ketiga auditor sebagai penilai dan suspense yang sudah berturut-turut diterima membuat BEI tidak memberikan kelonggaran bagi emiten dalam perbaikan pembayaran utang dikarenakan kelangsungan hidup yang diyakini akan menjurus kepada kerugian entitas dan bangkrut (Wareza, 2019).

Hal yang tidak kalah penting dari pengaruh BEI, yaitu pihak ketiga auditor yang akan menyampaikan hasil dari pelaporan keuangan emiten pada periode tertentu yang menentukan bagaimana status perusahaan saat ini maupun mendatang. BEI juga melakukan bagian tersendiri dari prosedur nya untuk tetap menjaga kestabilan. Apabila BEI sudah mencurigai kemungkinan emiten tidak mampu menjalankan usahanya maka opini auditor akan menjadi fokus utama BEI dalam menganalisa Laporan Keuangan Emiten. Emiten PT Sekawan Intipratama Tbk (SIAP) dan Arpeni Pratama Ocean Line Tbk (APOL) juga mendapat peringatan dari BEI akibat masalah kelangsungan hidup entitas yang menjelaskan 
bahwa opini audit going concern yang dikeluarkan seorang auditor memang sangat berpengaruh. permasalahan dari SIAP dan APOL yaitu tidak adanya pendapatan dan restrukturisasi hutang yang diyakini auditor sebagai masalah kelangsungan hidup yang akan berakibat pada kemacetan membayar hutang jangka panjang maupun pendeknya yang pada akhirnya suspense akan dikeluarkan BEI. Jika sudah 2 kali suspense maka delisting akan menjadi pilihan akhir. Delisting dari BEI sama saja dengan memperburuk keadaan emiten baik secara operasional maupun pengguanan saham karena kehilangan banyak investor dan beban yang semakin tinggi . Inilah yang menjadi alasan hipotesis self fullfing dipercaya apabila emiten menerima opini audit going concern perusahaan akan lebih cepat menuju kebangkrutan (Indrastiti, 2016).

"Dari hasil temuan auditor jika kesimpulan yang di dapat menyatakan ada kemungkinan perusahaan tidak dapat mempertahankan kesinambungan usahanya maka harus diterbitkan pada bagian opini dari auditor kewajaran dengan tidak ada pengeculian disertai penambahan khusus dalam laporan"(Hery, 2013). Muttaqin \& Sudarno (2012) menyatakan,”opini audit going concern berdampak negatif (bad news) bagi para pemakai laporan keuangan”. Inilah yang menjadi evaluasi penting seorang auditor dalam menyampaikan opininya, seorang auditor harus memuat dalam laporannya apabila dalam temuannya ditemukan permasalahan tingkat produktifitas sebuah entitas dalam jenjang keberlangsungan usaha (going concern) jika tidak dilampirkan akan menjadi kerugian besar bagi investor karena bagi investor itu sendiri laporan auditor adalah salah satu yang paling diandalkan investor dalam menilai kemampuan perusahaan dalam memberikan hasil dari 
pendanaan yang sudah diinvestasikan investor.

Kewaspadaan akan timbul untuk setiap pengguna laporan keuangan jika auditor mengeluarkan pendapat dari auditor konsistensi hidup perusahaan yang diartikan mereka menjadi awal kemerosotan keuangan entitas menuju kebangkrutan. Muttaqin \& Sudarno (2012) menegaskan,’berat bagi auditor untuk mengeluarkan opininya, fenomena tersebut dikarenakan hipotesis self fulfilling prophecy diantaranya menjelaskan keadaan entitas berubah menjadi lebih buruk bahkan menuju failed jika auditor memberikan pendapat konsistensi hidup perusahaan tidak berjalan dengan baik". Hery (2013) menyatakan,"faktor suatu perusahaan menerima opini audit going concern apabila keuangan perusahaan terus mengalami penurunan, ketidakmampuan perusahaan membayar hutang, kehilangan tingkat rasa kepercayaan dari pelanggan, manajemen yang buruk, perusahaan terus menerima pencitraan yang buruk, serta penurunan kinerja perusahaan mempengaruhi kelangsungan perusahaan”.

Suwardjono (2016) menyatakan,”teori perkontrakan efisien (efficient theory) salah satu pembagian dari teori keagenan (agency theory)". Dalam teori perkontrakan efisien digolongkan dari faktor-faktor dan kesimpulan hasil temuan ikatan keagenan. Ikatan keagenan ini merupakan ikatan antara pihak yang memberi kontrak (principal) dan pihak yang menerima kontrak (agent) dimana pihak agent dan principal memiliki hubungan timbal balik, pihak agen menjalankan tugas dari pihak principal dan pihak agen mendapatkan upah dari hasil kerjanya. Ikatan ini pada umumnya resmi dan didasari sebuah kontrak atau perjanjian. 
Untuk mencapai kontrak efisien ada dua faktor yang harus dipenuhi yaitu kontrak tersebut diusahakan kedua belah pihak menerima hasil sesuai yang diharapkan dari semua kinerja yang dilaksanakan agen dan tidak menimbulkan kesalahpahaman. Perihal penyampaian pelaporan keuangan, ikatan antara pemegang saham dan perusahaan dapat dinilai sebagai ikatan keagenan. Investor berperan menjadi principal dan perusahaan berperan menjadi agent. Maka dari itu tindakan perusahaan dapat digambarkan dari teori keagenan tersebut. Pada dasarnya pihak principal dan agen membutuhkan kesepakatan supaya mendapatkan keuntungan dan pada umumnya hanya memikirkan untung bagi pihak sendiri tanpa memperhitungkan dampak bagi pihak kedua. Oleh karena itu, akibatnya akan menimbulkan keadaan yang kompleks pada kontrakefisien.

Apabila emiten mempunyai rasio likuiditas (diproksikan rasio lancar) yang stabil dan bagus dengan demikian keadaan tersebut perusahaan dikatakan mampu mempertahankan kelangsungan usaha. Oleh karena itu, perusahaan masih berada dalam posisi aman dan kecil kemungkinan mendapat opini audit going concern, tetapi hasil yang dikeluarkan oleh Putra \& Arisman (2017) menyatakan,"rasio likuiditas berpengaruh positif dimana besar kecil rasio likuiditas perusahaan akan mempengaruhi suatu perusahaan mendapat opini audit going concern". Penelitian Muttaqin \& Sudarno (2012) membuktikan pernyataan,"rasio lancar berpengaruh negatif terhadap penerimaan opini audit going concern”. Begitu juga dalam pengujian Melania et al., (2016); Utami et al., (2017).

H1: Rasio likuiditas berpengaruh positif terhadap penerimaan opini audit going concern. 
Saat perusahaan memiliki profitabilitas (diproksi dengan ROA) yang memcapai sesuai dengan target yang ditentukan oleh perusahaan dan ROA (rasio perputaran aset) yang tinggi membuat entitas akan mendapat laba yang lebih baik dan dapat dikatakan mampu menjalankan kelangsungan usahanya, sehingga kemungkinan untuk menerima opini audit going concern semakin kecil. Demikian penelitian Muttaqin \& Sudarno (2012); Putra \& Arisman (2017); Utami et al., (2017) yang membuktikan bahwa rasio profitabilitas berpengaruh positif terhadap penerimaan opini audit going concern. Penelitian Alamanda (2015); Kusumawardhani (2018); Gusti \& Yudowati (2018) menyatakan rasio profitabilitas berpengaruh negatif dikarenakan rasio yang rendah bukan berarti buruk.

H2: Rasio profitabilitas berpengaruh positif terhadap penerimaan opini audit going concern.

Rasio leverage diaplikasikan guna menilai seberapa besar kemampuan perusahaan dibiayai oleh hutang. Apabila perusahaan menggunakan hutang lebih besar dari aktiva yang dimiliki maka besar kemungkinan perusahan akan gulung tikar dalam jangka waktu dekat. Dalam penelitian penelitian Herawati \& Hendra (2015) menyatakan bahwa rasio leverage berpengaruh positif terhadap opini audit going concern. Sedangkan Muttaqin \& Sudarno (2012); Salean \& Zaroni (2013); Wibisono (2013) bahwa rasio leverage terhadap penerimaan audit going concern berpengaruh negatif.

H3: Rasio leverage berpengaruh positif terhadap penerimaan opini audit going concern. 
Rasio aktivitas (diproksi dengan Total Asset Turn Over / TATO) menunjukkan keadaan perusahaan dalam bagian pengelolaan aktiva. Kinerja manajemen dapat diukur dari efesiensi perusahaan dan efektifitas dalam mempergunakan aset perusahaan dan mencapai tujuan perusahaan secara maksimal. Semakin meningkat rasio aktivitas menggambarkan pengelolaan aktiva dalam keadaan baik dan dapat dikatakan mencapai kelangsungan usaha, tetapi penelitian Muttaqin \& Sudarno (2012) berbanding terbalik menyatakan bahwa berpengaruh positif terhadap opini audit going concern.

H4: Rasio aktivitas berpengaruh positif terhadap penerimaan opini audit going concern.

"Periode laporan keuangan yang diselesaikan serta diaudit pada tanggal 31 Desember" (Suryani, 2014). Pada umumnya perusahan yang besar harus tepat waktu dalam menyelesaikan laporan independen agar tidak menimbulkan kecurigaan investor. Tetapi jika ditemukan opini audit going concern dengan cakupan sajian laporan auditor kemungkinan bagian manejemen hendak berusaha menemukan cara agar opini tersebut tidak dikeluarkan atau auditor mengevaluasi kembali untuk waspada apabila opini dapat berubah. Hal inilah yang akan menyebabkan keterlambatan dalam pengeluaran pelaporan keuangan yang sudah diaudit. Penelitian Praptitorini \& Januarti (2011) menyatakan bahwa "audit lag berpengaruh positif terhadap penerimaan opini audit going concern”. Sedangkan penelitian Muttaqin \& Sudarno (2012); Salean \& Zaroni (2013), “menyatakan bahwa audit lag berpengaruh negatif terhadap penerimaan opini audit going concern”. 
H5: Audit lag berpengaruh positif terhadap penerimaan opini audit going concern.

Hubungan antara KAP dan perusahaan yang cukup lama akan menimbulkan kurangnya penilaian auditor secara obyektif yang memicu timbulnya keraguan moral dan etika auditor dan juga kurangnya independensi KAP terhadap perusahaan. Oleh sebab itu, untuk mengurangi tingkat kecurangan dalam penilaian auditor yang tidak objektif maka ditentukan jangka waktu bagi KAP untuk mengaudit suatu perusahaan. Jangka waktu yang ditentukan bagi KAP dan perusahaan melakukan kerja sama yaitu selama 5 tahun. Menurut Dewayanto (2011) mengemukakan,"dari hal tersebut auditor harus mampu mempertahakan independensinya dalam arti tidak menilai secara subyektif mengingat lamanya hubungan antara auditor dan auditee tetapi harus tetap obyektif dalam memberikan opini walaupun pihak perusahaan menawarkan fee yang besar sehingga akan berdampak kepada obyektifitas auditor dalam memberikan opininya". Penelitian yang dilakukan Dewayanto (2011); Dewi \& Kusuma (2018); Muttaqin \& Sudarno (2012) audit client tenure berpengaruh positif terhadap penerimaan opini audit going concern. Sedangkan penelitian Florentina (2016); Krissindiastuti \& Rasmini (2016); Nainggolan (2016); Putri \& Primasari (2016) menyatakan bahwa audit clien tenure berpengaruh negatif terhadap penerimaan opini audit going concern.

H6: Audit client tenure berpengaruh positif terhadap penerimaan opini audit going concern.

Apabila seorang auditor memberikan opini audit going concern pada perusahaan maka manejemen perusahaan akan kewalahan dan mencari alternatif 
lain untuk memperbaiki reputasi perusahaan yaitu mengadakan pertukaran auditor. Dalam pergantian auditor diyakini memberi pengaruh posistif pada pendapat dari auditor mengenai kelangsungan hidup perusahaan (going concern). Pihak manejemen akan berusaha mencari auditor yang akan memberikan opini yang baik terhadap perusahaan. Peristiwa yang demikian disebut sebagai opinion shopping. Hal ini akan dilakukan manejemen mengingat kepentingan investor dan pemberi dana lainnya dapat memperngaruhi kelangsungan hidup perusahaan. Hal ini ditegaskan kembali oleh Praptitorini \& Januarti (2011) menyatakan "Perusahaan yang mengalami masalah keuangan biasanya akan melakukan pergantian auditor untuk menghindari opini audit going concern. Dalam keadaan tersebut bisa saja terjadi pemberian opini baru atau hanya sekedar mengganti auditor". Hasil dari penelitian Krissindiastuti \& Rasmini (2016); Muttaqin \& Sudarno (2012) juga menyatakan opinion shopping berpengaruh posistif terhadap pendapat dari auditor mengenai kelangsungan hidup perusahaan. Penelitian Anggelina et al., (2018); Dewayanto (2011); Kartika (2012); Putra \& Arisman (2017); Tarihoran \& Budiono (2016); Utami et al., (2017) menjelaskan hasil opinion shopping berpengaruh negatif terhadap penerimaan opini audit going concern.

H7: Opinion shopping berpengaruh positif terhadap penerimaan opini audit going concern.

Keberhasilan KAP dalam menangani kliennya dapat dilihat dari pengalaman dan tingkat kemampuan. Dalam hal ini, pergantian auditor disebabkan perusahaan tidak selalu setuju apabila ditemukan pendapat dari auditor mengenai konsistensi hidup perusahaan pada cakupan isi laporan perusahaan mereka. 
Muttaqin \& Sudarno (2012) menyatakan,"ukuran kantor akuntan tidak selalu berdampak dengan penilaian opini auditor terhadap perusahaan, baik buruknya opini audit dapat dinilai dari kualitas auditornya". Ini membuktikan bahwa setiap auditor perlu banyak pengalaman dan pencapaian yang sudah dilakukan karena menyangkut kejelasan perusahaan klien. Pada dasarnya, perusahaan yang mendapat opini audit going concern masih saja menjadi masalah yang dapat mempengaruhi produktifitas perusahaan karena penjabaran dari hal yang memutuskan bahwa going concern dapat diketahui alasan dan faktornya masih tidak jelas. Kantor KAP big four memiliki karir yang bagus dan masih dapat dipercaya mengingat kualitas auditornya serta jasa mereka sudah diakui dan digunakan secara internasional. Jika melihat posisi big four yang top maka mereka akan menjaga reputasi mengingat kontrak kerja mereka yang besar maka dapat dikatakan mereka akan memberikan opini audit going concern lebih banyak dari kantor akuntan non big four, itu pun jika terdapat temuan mengenai ketidakmampuan perusahaan mempertahankan usahanya Muttaqin \& Sudarno (2012). Penelitian Dewi \& Kusuma (2018); Krissindiastuti \& Rasmini (2016) menyatakan bahwa reputasi KAP berpengaruh positif terhadap penerimaan opini audit going concern. Sedangkan penelitian Dewayanto (2011); Florentina (2016); Putri \& Primasari (2016); Tamir \& Anisykurlillah (2014); Tarihoran \& Budiono (2016) menyatakan berpengaruh negatif terhadap penerimaan opini audit going concern.

H8: Reputasi KAP berpengaruh positif terhadap penerimaan opini audit going concern. 


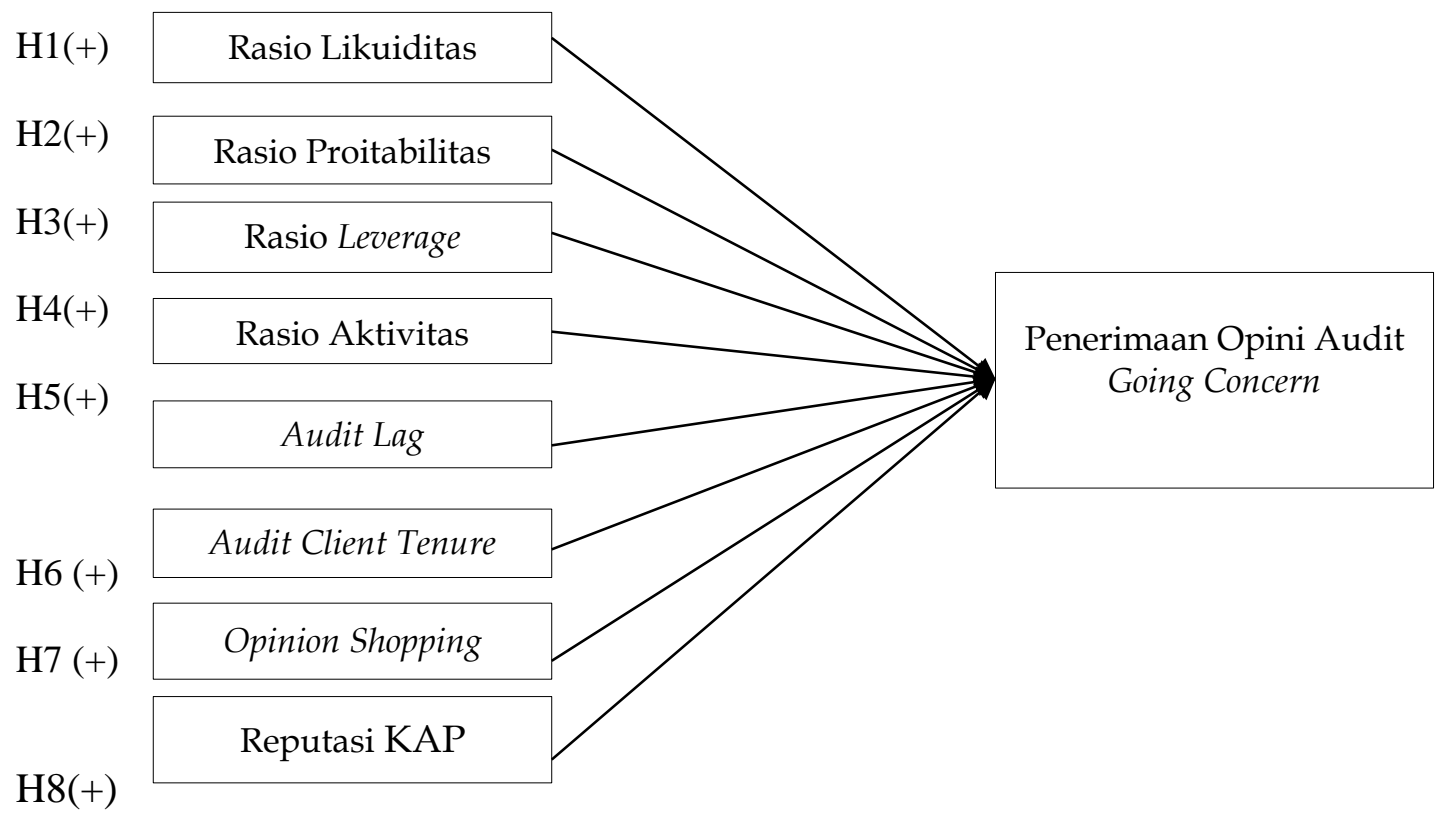

Sumber: Data sekunder,2019

Gambar 1.

Model Penelitian

\section{METODE PENELITIAN}

Sugiono \& Untung (2016) mengatakan,"penelitian kuantitatif dalam melihat hubungan variabel terhadap obyek yang diteliti lebih bersifat sebab akibat (kausal) sehingga dalam penelitiannya ada variabel independen dan dependen". Dari variabel tersebut selanjutnya dicari seberapa besar pengaruh variabel independen terhadap variabel dependen. Sugiono \& Untung (2016) "metode kuantitatif dinamakan metode tradisional karena metode ini sudah cukup lama digunakan sehingga sudah mentradisi sebagai metode untuk penelitian”. Metode ini disebut sebagai positifistik karena berlandaskan pada filsafat positifisme. Metode ini disebut metode kuantitatif karena data penelitian berupa angka-angka dan 
analisis menggunakan statistik. Penentuan sampel dalam penelitian ini yaitu populasi dalam penelitian merupakan keseluruhan perusahaan manufaktur yang terdaftar di BEI. Pada penelitian ini yang menjadi sampel yakni :

\section{Tabel 1.}

\section{Kriteria Pengambilan Sampel}

\begin{tabular}{clc}
\hline No. & \multicolumn{1}{c}{ Kriteria } & Jumlah \\
\hline 1. & $\begin{array}{l}\text { Entitas sektor manufaktur listing dan mempublikasi laporan keuangan di } \\
\text { BEI tahun 2016-2018. }\end{array}$ & 144 \\
2. & $\begin{array}{l}\text { Tidak memperoleh net profit periode financial report selama tahun 2016- } \\
\text { 2018. }\end{array}$ & (57) \\
3. & Laporan keuangan yang berakhir tanggal 31 Desember. \\
4. & Laporan yang telah diaudit tapi tidak lengkap tahun 2016- 2018. \\
& $\quad$ Jumlah sampel untuk periode peneliti \\
& Jumlah sampel selama 3 tahun & $(23)$ \\
\end{tabular}

Sumber: Data Penelitian, 2019

Data yang digunakan data sekunder, tempat penelitian pada sumber sekunder pengujian BEI. Bahan acuan penelitian dari (Laporan Keuangan dan Tahunan, 2019)

"Rasio Likuiditas (diproksikan Current Asset Ratio/CAR) Rasio yang digunakan untuk mengukur kemampuan perusahaan dalam membayar kewajiban jangka pendeknya dengan menggunakan aktiva lancar yang dimiliki" (Sujarweni, 2017).

Current Asset Ratio $=\frac{\text { Total Current Assets }}{\text { Total current Liabilities }}$

"Rasio Profitabilitas (diproksi Return On Asset/ ROA) pada umumnya jika rasio return on asset meningkat, perusahaan akan memperoleh laba atas penjualan serta laba atas aktiva yang lebih baik" (Sugiono \& Untung, 2016). 
Return On Assets $=\frac{\text { Pre tax Income }}{\text { Total Assets }}$

"Rasio Leverage (diproksi debt to equity ratio) rasio ini salah satu rasio yang penting, berhubungan dengan masalah trading on equity memberikan pengaruh terhadap rentabilitas modal sendiri dari perusahaan" (Sugiono \& Untung, 2016).

Debt to equity ratio $=\frac{\text { Total Liabilities }}{\text { Total Equity }}$

"Rasio Aktivitas (diproksiTotal Asset Turn Over/TATO) secara umum semakin besar rasio TATO (Total Asset Turn Over) akan semakin bagus karena menunjukkan kemampuan perusahaan untuk mengelola asset” (Sugiono \& Untung, 2016).

Total Assets Turn Over $=\frac{\text { Net sales }}{\text { Total Assets }}$

"Audit Lag diartikan dengan keseluruhan tanggal kalender sampai dengan selesainya laporan keuangan (31 bulan ke 12) dengan jumlah tanggal berakhirnya pekerjaan auditor di lapangan"(Muttaqin \& Sudarno, 2012). Audit Lag diukur menggunakan variabel dummy dengan kategori 1 apabila tepat waktu , 0 apabila yang tidak tepat waktu. (Wendy et al., 2019).

“Audit client tenure didefinisikan sebagai keseluruhan tahun pada saat KAP melakukan pengerjaan pengauditan pada satu perusahaan. Audit client tenure diukur dengan menghitung tahun dimana KAP yang telah melakukan perikatan audit terhadap perusahaan” (Muttaqin \& Sudarno, 2012).

“Opinion Shopping didefinisikan oleh SEC, sebagai aktivas mencari auditor yang mau mendukung perlakuan akuntansi yang diajukan oleh manejemen untuk 
tujuan pelaporan perusahaan. Jika melakukan perukaran auditor 1, jika tidak melakukan pertukaran auditor 0” (Praptitorini \& Januarti, 2011).

"Keunggulan sebuah KAP yang tergolong dalam top KAP Big Four dipandang lebih meyakinkan dari KAP yang tanpa kategori top dalam lingkup top KAP. Jika termasuk big four 1, jika tidak termasuk Big Four 0" (Tamir \& Anisykurlillah, 2014).

Opini audit going concern merupakan opini audit yang dalam pertimbangan auditor terhadap ketidakmampuan atau ketidakpastian signifikan atas kelangsungan hidup perusahaan dalam menjalankan operasinya pada kurun waktu yang pantas tidak lebih dari satu tahun sejak tanggal laporan keuangan yang sedang diaudit. Penerimanaan opini audit going concern diukur dari Variabel dummy, jika menerima opini audit going concern 1,jika tidak menerima opini audit going concern 0 (Sari et al., 2016).

Opini audit going concern adalah variabel dependen dalam penelitian ini. Opini audit wajar tanpa pengecualian dengan paragraf penjelas dalam opini audit going concern merupakan adanya kecurigaan auditor pada perusahaan mengenai kelangsungan hidup perusahaan di waktu yang akan datang. Menurut Ghozali (2016) “variabel dummy, permasalahan yang sering dihadapi adalah variabel independen yang berskala non-metrik atau kategorial. Menguji hipotesis ini tidak memerlukan uji normalitas dan tidak memerlukan multikolonieritas". Persamaan regresi logistik yaitu : 


$$
\begin{aligned}
\operatorname{Ln} \frac{G c}{1-G c}=a & +b 1 \text { LIKD }+b 2 \text { PROFft }+b 3 a L E V R+b 4 A K T+b 5 L A G \\
& +b 6 T E N+b 7 \text { SHOP }+b 8 R E P+e
\end{aligned}
$$

Keterangan :

$$
\begin{array}{ll}
\operatorname{Ln} \frac{G c}{1-G c} & =\text { Opini audit going concern } \\
\text { a } & =\text { Nilai tetap } \\
\text { LIKD } & =\text { Liquidity Ratio } \\
\text { PROF } & =\text { Profibility Ratio } \\
\text { LEVR } & =\text { leverage Ratio } \\
\text { AKT } & =\text { Activity Ratio } \\
\text { LAG } & =\text { Audit lag } \\
\text { TEN } & =\text { Audit client tenure } \\
\text { SHOP } & =\text { Opinion shopping } \\
\text { REP } & =\text { Reputasi KAP } \\
\mathrm{e} & =\text { Errorterm }
\end{array}
$$

\section{HASIL DAN PEMBAHASAN}

Hosmer and Lemeshow Test dilakukan untuk melihat perbandingan antara model dengan nilai observasi. Hal ini dapat di nilai dari pengujian Hosmer and Lemeshow Test sesuai ketentuan sebagai berikut :

$\mathrm{H}_{\mathrm{a}}$ : apabila hasil uji Hosmer and Lemeshow Test lebih besar dari nilai signifikansi 0,05 maka hipotesis diterima.

$\mathrm{H}_{0}$ : apabila hasil uji Hosmer and Lemeshow Test lebih kecil dari nilai nilai signifikansi 0,05 maka hipotesis ditolak.

Tabel 2.

Hosmer and Lemeshow Test

\begin{tabular}{cccc}
\hline Step & Chi-square & df & Sig. \\
1 & 7,353 & 8 & 0,499 \\
\hline \multicolumn{2}{l}{ Sumber: }
\end{tabular}


Dari Tabel 2 diperoleh hasil signifikan dalam uji Hosmer and Lemeshow Test adalah 0,499>0,05 (sign), model regresi faktor bebas antara lain liquidity ratio, profibility ratio, leverage ratio, activity ratio, audit lag, audit client tenure, opinion shopping dan reputasi KAP, terhadap opini audit going concern adalah baik (fit), maka dapat dikatakan bahwa regresi logistik mumpuni untuk menjabarkan variabel penelitian.

Statistik deskriptif diuji guna melihat faktor apa saja yang dipakai untuk penelitian. Berdasarkan hasil pengolahan SPSS 23 yang meliputi 8 variabel didapat hasil data untuk uji statistik deskriptif dari semua faktor bebas sebagai berikut:

Tabel 3.

Descriptive Statistics

\begin{tabular}{lccccc}
\hline & N & Minimum & $\begin{array}{c}\text { Maximu } \\
\text { m }\end{array}$ & Mean & $\begin{array}{c}\text { Std. } \\
\text { Deviation }\end{array}$ \\
\hline GC & 180 & 0 & 1 & 0,41 & 0,492 \\
LIKD & 180 & 0,60563 & 289,63596 & 4,189497 & 21,4871689 \\
PROF & 180 & 0,00007 & 77,48692 & 0,517267 & 5,77077343 \\
LERV & 180 & $-2,2145$ & 1335,5603 & 8,761885 & 99,6545746 \\
AKT & 180 & 0 & 1132,1084 & 7,330693 & 84,3065319 \\
LAG & 180 & 0 & 1 & 0,99 & 0,105 \\
TEN & 180 & 0 & 1 & 0,4 & 0,491 \\
SHOP & 180 & 0 & 1 & 0,22 & 0,417 \\
REP & 180 & 0 & 1 & 0,47 & 0,501 \\
Valid N & 180 & & & & \\
(listwise) & 180 & & & &
\end{tabular}

Dari riset yang sudah diuji untuk 8 variabel independen dimana sampel sebanyak 180 yang listing di BEI pada tahun 2016-2018 dan sesuai seperti kriteria yang ditentukan. Faktor rasio likuiditas yang diproksikan terhadap CAR menunjukkan seberapa besar aktiva lancar dapat membayar hutang jangka panjang perusahaan. Adapun nilai minimum yang diperoleh sebesar 0,60563 dimana nilai ini didapat dari perusahaan PT.Unilever periode 2016 dan nilai maksimum 
diperoleh sebesar 289,63596 dimana nilai ini didapat dari perusahaan PT.Garuda Melindo periode 2017. Sedangkan nilai mean diperoleh sebesar 4,18949 dan sandart deviation sebesar 21,48716. Variabel profitabilitas yang diproksikan terhadap ROA menunjukkan seberapa besar laba yang diperoleh melalui aset yang dimiliki perusahaan. Dari hasil pengujian didapat hasil nilai minimum sebesar 0,00007 yang didapat dari perusahaan PT.Petrocham periode 2016 dan nilai maksimum 77,48692 yang didapat dari perusahaan PT. Sepatu Bata periode 2018. Sedangkan hasil mean sebesar 0,51726 dan nilai standart deviation sebesar 5,77077 .

Variabel leverage yang diproksikan terhadap DER yang menunjukkan seberapa besar modal perusahaan digunakan untuk membayar hutang jangka panjang perusahaan. Adapun nilai minimum yang diperoleh sebesar -2,21451 yang didapat dari perusahaan PT.Bintang Karisma periode 2018 dan nilai maximum sebesar 1335,56027 yang diperoleh dari perusahaan PT.Argha Karya Prima Industri periode 2016. Sedangkan nilai mean sebesar 8,76188 dan nilai standart deviation sebesar 99,65457. Variabel aktivitas yang diproksikan terhadap TATO yang nunjukkan seberapa besar perputaran aset yang diperoleh atas penjualan perusahaan. Nilai minimum yang diperoleh sebesar 0,0000013 yang didapat dari perusahaan PT.Pyridam Farma dan nilai maximum sebesar 1132,10843 yang didapat dari perusahaan PT.Sepatu Bata. Sedangkan nilai mean diperoleh sebesar 7,33069 dan nilai standart deviation sebesar 84,30653.

Variabel audit lag menunjukkan ketepatan suatu perusahaan dalam melaporkan laporan keuangan perusahaan, apakah melaporkan sesuai dengan 
waktu yang ditetapkan atau tidak. Dari hasil uji diperoleh nilai minimum yaitu 0 dan nilai maximum yaitu 1 . Sedangkan hasil meannya sebesar 0,99 dan juga standart deviation sebesar 0,105.Variabel audit client tenure menunjukkan seberapa lama perikatan antara KAP dan perusahaan yang diaudit untuk melihat apakah perikatan kedua pihak tersebut dapat mempengaruhi pemberian pendapat auditor mengenai kelangsungan hidup terhadap perusahaan. Adapun hasil minimum yang diperoleh yaitu 0 dan hasil maksimum yaitu 1 , sedangkan hasil mean yang diperoleh 0,40 serta nilai standart deviation sebesar 0,491.

Variabel opinion shopping menunjukkan seberapa lama perikatan antara auditor dan perusahaan yang diaudit dan juga melihat apakah perusahaan mengganti auditor yang dipakai sesuai dengan ketentuan yang telah ditetapkan guna untuk menghindari terjadinya kerja sama antar kedua pihak dalam memberikan opini. Hasil uji menunjukkan nilai minimum yang diperoleh yaitu 0 dan nilai maximum yaitu 1. Sedangkan hasil mean sebesar 0,22 dan hasil standart deviation sebesar 0,417. Variabel reputasi KAP digunakan untuk melihat seberapa besar pengaruh yang diberikan KAP skala besar seperti big four atau pun yang KAP skala kecil yang non big four dalam memberikan pendapat auditor mengenai kelangsungan hidup kepada suatu perusahaan. Dari uji yang dilakukan didapatkan hasil minimum ialah 0 sedangkan hasil maksimum ialah 1 . Sedangkan hasil mean diperoleh yaitu 0,47 serta hasil standart deviation sebesar 0,501.

Tabel matriks klasifikasi digunakan untuk menilai seberapa besar kemungkinan prediksi dari variabel terkait yang di uji dengan menggunakan nilai persentase. 
Tabel 4.

Classification Table

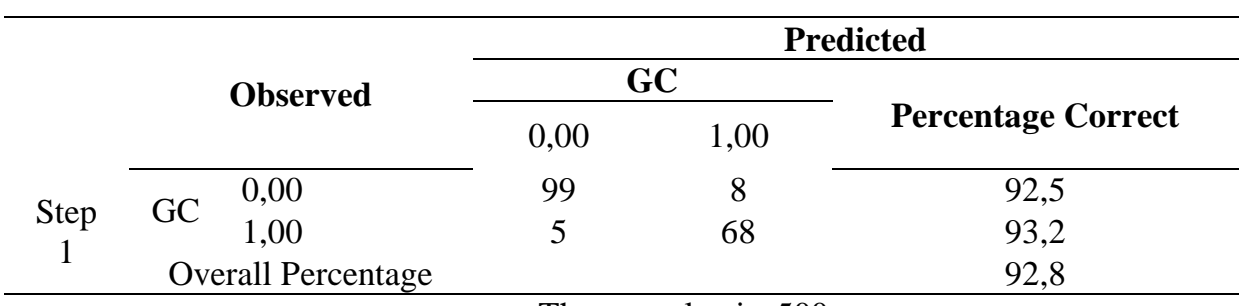

a. The cut value is , 500

Sumber: Data Penelitian, 2019

Pada Tabel 4 menunjukkan hasil yang didapat melalui 180 sampel penelitian.

Prediksi peluang suatu emiten menerima opini audit going concern ialah 93,2\%. Sebayak 68 laporan keuangan emiten menerima opini audit going concern dari keseluruhan sebanyak 73 laporan keuangan yang selayaknya menerima opini audit going concern. Sedangkan perkiraan terhadap emiten yang tidak menerima opini audit going concern ialah 92,5\% dimana dapat diketahui melalui uji model regresi sejumlah 99 laporan keuangan tidak menerima opini audit going concern atas keseluruhan 107 laporan keuangan dimana selayaknya tidak menerima opini audit going concern.

Dari Tabel 5 dapat dilihat bagaimana faktor bebas yang telah diteliti dapat berpengaruh untuk memperbaiki model penelitian. Jika Chi Square tabel lebih tinggi dibandingkan Chi Square hitung maka bentuk data tersebut fit dan diterima sedangkan jika Chi Square tabel lebih kecil dari Chi Square hitung maka bentuk data dikatan tidak fit dan ditolak. Penelitian ini dihitung berdasarkan rumus yaitu mengurankan hasil dari -2 Log Likelihood awal yang di dapat dari Blok $0=$ Begining Blok dalam SPSS dengan hasil -2 Log Likelihood akhir yang didapat dari Blok $1=$ Method Enter dalam SPSS. 
Tabel 5.

-2 Log Likelihood Awal Iteration History ${ }^{\mathrm{a}, \mathrm{b}, \mathrm{c}}$

\begin{tabular}{rrcc}
\hline \multirow{2}{*}{ Iteration } & & -2 Log likelihood & Coefficients \\
& 1 & 243,073 & Constant \\
\multirow{3}{*}{ Step 0 } & 2 & 243,072 & $-0,378$ \\
& 3 & 243,072 & $-0,382$ \\
\hline
\end{tabular}

a. Constant is included in the model.

b. Initial -2 Log Likelihood: 243,072

c. Estimation terminated at iteration number 3 because parameter estimates changed by less than ,001.

Sumber: Data Penelitian, 2019

Tabel 6.

\section{-2 Log Likelihood Akhir Iteration History ${ }^{\mathrm{a}, \mathrm{b}, \mathrm{c}, \mathrm{d}}$}

\begin{tabular}{|c|c|c|c|c|c|c|c|c|c|c|c|}
\hline \multirow{2}{*}{\multicolumn{2}{|c|}{ Iteration }} & \multirow{2}{*}{$\begin{array}{c}-2 \text { Log } \\
\text { likelihoo } \\
\text { d }\end{array}$} & \multicolumn{9}{|c|}{ Coefficients } \\
\hline & & & $\begin{array}{c}\text { Constan } \\
\mathbf{t} \\
\end{array}$ & $\begin{array}{c}\text { LIK } \\
\text { D }\end{array}$ & PROF & LERV & AKT & LAG & TEN & $\begin{array}{c}\text { SHO } \\
\mathbf{P} \\
\end{array}$ & REP \\
\hline \multirow{20}{*}{$\begin{array}{c}\text { Step } \\
1\end{array}$} & 1 & 117,165 & $-2,3$ & $\begin{array}{c}- \\
0,003\end{array}$ & $-1,148$ & 0,001 & 0,079 & 0,742 & 2,11 & 2,395 & $-0,362$ \\
\hline & 2 & 95,819 & $-3,811$ & $\begin{array}{c}- \\
0,006\end{array}$ & $-1,602$ & 0,002 & 0,11 & 1,433 & 3,291 & 3,994 & $-0,578$ \\
\hline & 3 & 90,506 & $-4,558$ & $\begin{array}{c}- \\
0,023\end{array}$ & $-1,658$ & 0,004 & 0,113 & 1,594 & 4,071 & 5,112 & $-0,718$ \\
\hline & 4 & 82,375 & $-2,883$ & $\begin{array}{c}- \\
0,362\end{array}$ & $-1,463$ & 0,008 & 0,099 & 0,714 & 4,025 & 5,024 & $-0,831$ \\
\hline & 5 & 80,073 & $-1,736$ & $\begin{array}{c}- \\
0,549\end{array}$ & $-1,673$ & 0,036 & 0,114 & $-0,194$ & 4,228 & 4,988 & $-0,971$ \\
\hline & 6 & 78,238 & $-0,804$ & $\begin{array}{c}- \\
0,575\end{array}$ & $-1,641$ & 0,119 & 0,112 & $-1,164$ & 4,239 & 5,002 & $-1,019$ \\
\hline & 7 & 66,432 & $-0,406$ & - & $-0,468$ & 1,273 & 0,031 & $-2,66$ & 3,673 & 4,439 & $-1,207$ \\
\hline & 8 & 65,185 & 0,101 & $\begin{array}{c}- \\
0,441\end{array}$ & $-0,85$ & 1,54 & 0,058 & $-3,179$ & 3,984 & 4,577 & $-1,447$ \\
\hline & 9 & 65,136 & 0,977 & $\begin{array}{c}- \\
0,466\end{array}$ & $-0,932$ & 1,612 & 0,063 & $-4,068$ & 4,067 & 4,619 & $-1,525$ \\
\hline & 10 & 65,136 & 1,971 & $\begin{array}{c}- \\
0,467\end{array}$ & $-0,937$ & 1,615 & 0,064 & $-5,063$ & 4,072 & 4,622 & $-1,53$ \\
\hline & 11 & 65,136 & 2,971 & 0,467 & $-0,937$ & 1,615 & 0,064 & $-6,063$ & 4,072 & 4,622 & $-1,53$ \\
\hline & 12 & 65,136 & 3,971 & 0,467 & $-0,937$ & 1,615 & 0,064 & $-7,063$ & 4,072 & 4,622 & $-1,53$ \\
\hline & 13 & 65,136 & 4,971 & $\begin{array}{c}- \\
0,467\end{array}$ & $-0,937$ & 1,615 & 0,064 & $-8,063$ & 4,072 & 4,622 & $-1,53$ \\
\hline & 14 & 65,136 & 5,971 & 0,467 & $-0,937$ & 1,615 & 0,064 & $-9,063$ & 4,072 & 4,622 & $-1,53$ \\
\hline & 15 & 65,136 & 6,971 & $\begin{array}{c}- \\
0,467\end{array}$ & $-0,937$ & 1,615 & 0,064 & $\begin{array}{c}- \\
10,063\end{array}$ & 4,072 & 4,622 & $-1,53$ \\
\hline & 16 & 65,136 & 7,971 & 0,467 & $-0,937$ & 1,615 & 0,064 & 11,063 & 4,072 & 4,622 & $-1,53$ \\
\hline & 17 & 65,136 & 8,971 & $\begin{array}{c}- \\
0,467\end{array}$ & $-0,937$ & 1,615 & 0,064 & $\begin{array}{c}- \\
12,063\end{array}$ & 4,072 & 4,622 & $-1,53$ \\
\hline & 18 & 65,136 & 9,971 & $\begin{array}{c}- \\
0,467\end{array}$ & $-0,937$ & 1,615 & 0,064 & 13,063 & 4,072 & 4,622 & $-1,53$ \\
\hline & 19 & 65,136 & 10,971 & 0,467 & $-0,937$ & 1,615 & 0,064 & $\begin{array}{c}- \\
14,063\end{array}$ & 4,072 & 4,622 & $-1,53$ \\
\hline & 20 & 65,136 & 11,971 & 0,467 & $-0,937$ & 1,615 & 0,064 & 15,063 & 4,072 & 4,622 & $-1,53$ \\
\hline
\end{tabular}




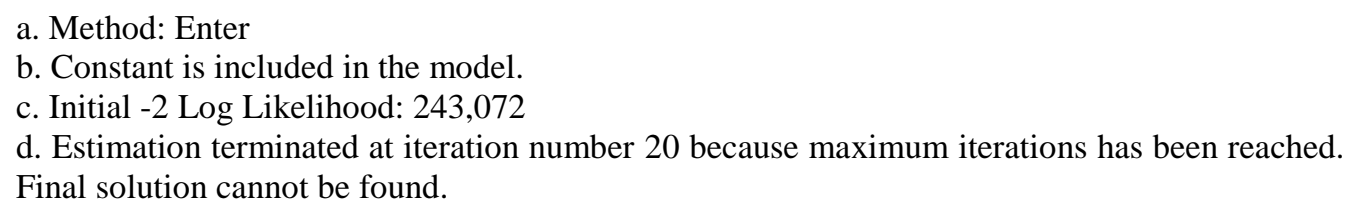

Sumber : Data Penelitian, 2019

Dari Tabel 5 dan Tabel 6 diperoleh hasil -2 Log Likelihood awal sebesar 243,072 didapat dari table uji iteration history blok 0 dan hasil -2 Log Likelihood akhir sebesar 65,136 didapat dari table uji iteration history blok 1. Artinya dari hasil -2 Log Likelihood terjadi penurunan sebesar 177,936. Oleh sebab itu, dikatakan bahwa data fit dan diterima.

Koefisien determinasi merupakan uji guna melihat seberapa besar pengaruh keseluruhan faktor bebas dalam menjelaskan variabel terikat. Keadaan tersebut bisa diketahui dengan pengujian model summary yaitu nilai Cox \& Snell R Square dan Nagelkerke R Square. Dimana Nagelkerke R Square diuji guna mendapat persenan dari variable terikat dipengaruhi oleh variable bebas. Berikut tabel hasil uji model summary:

Tabel 7. Model Summary

\begin{tabular}{lccc}
\hline Step & -2 Log likelihood & Cox \& Snell R Square & Nagelkerke R Square \\
1 & $65,136^{\mathrm{a}}$ & 0,628 & 0,847 \\
\hline a. Estimation terminated at iteration number 20 because maximum iterations has been \\
reached. Final solution cannot be found \\
mber:Data Penelitian, 2019
\end{tabular}

Dari Tabel 7 dapat diketahui bahwa nilai dari Cox \& Snell R Square sebesar 0,628 sedangkan Nagelkerke $R$ Square sebesar 0,847. Sehingga dapat ditarik kesimpulan bahwa sebesar $84,7 \%$ variabilitas (variasi) faktor terikat (going concern) dipengaruhi oleh faktor bebas secara bersamaan, dan sisanya sebesar 
$15,3 \%$ ialah faktor yang tidak dapat pengaruh dari faktor yang tidak diteliti seperti ukuran perusahaan, price to book value ratio dan lainnya sebagaimana seperti faktor uji riset tersebut.

Uji terakhir yaitu koefisien regresi logistik, uji ini digunakan untuk menilai hubungan faktor bebas dengan faktor terikat melalui perbandingan antara probabilitas (sign) dan tingkat signifikansi $(\alpha)$. Berikut ini hasil dari uji koefisien regresi logistik :

Tabel 8.

Variables in the Equation

\begin{tabular}{cccccccc}
\hline & & B & S.E. & Wald & df & Sig. & Exp(B) \\
\cline { 3 - 7 } & LIKD & $-0,467$ & 0,264 & 3,14 & 1 & 0,076 & 0,627 \\
& PROF & $-0,937$ & 1,88 & 0,249 & 1 & 0,618 & 0,392 \\
& LERV & 1,615 & 0,49 & 10,843 & 1 & 0,001 & 5,028 \\
\multirow{3}{*}{$1^{\mathrm{a}}$} & AKT & 0,064 & 0,13 & 0,243 & 1 & 0,622 & 1,066 \\
& LAG & $-15,063$ & 27767,8 & 0 & 1 & 1 & 0 \\
& TEN & 4,072 & 0,864 & 22,194 & 1 & 0 & 58,667 \\
& SHOP & 4,622 & 1,03 & 20,137 & 1 & 0 & 101,671 \\
& REP & $-1,53$ & 0,758 & 4,071 & 1 & 0,044 & 0,217 \\
& Constant & 11,971 & 27767,8 & 0 & 1 & 1 & 158038 \\
\hline
\end{tabular}

a. Variable(s) entered on step 1: LIKD, PROF, LERV, AKT, LAG, TEN, SHOP, REP. Sumber: Data Penelitian, 2019

Dalam uji hipotesis menggunakan model regresi logistik dapat dilihat dengan membandingkan hasil uji variabel dalam kolom signifikan dengan nilai tingkat signifikansi $(\alpha)$ yaitu 5\% (0,05). Dimana apabila nilai signifikan tabel $<0,05$ maka hipotesis dapat diterima tapi jika nilai signifikan tabel $>0,05$ maka hipotesis tidak dapat diterima. Dari uji hipotesis terhadap variabel didapat hasil yaitu sebanyak 4 hipotesis diterima dan 4 hipotesis tidak diterima. Berikut dijabarkan penjelasannya:

Pada uji terhadap rasio likuiditas H1 ditolak. Dimana dinyatakan bahwa rasio likuditas berpengaruh negatif terhadap penerimaan opini audit going concern 
karena nilai tingkat signifikansi lebih kecil dari nilai signifikannya yaitu $0,05<0,078$. Keseimbangan aset lancar perusahaan yang cenderung lebih rendah tidak berkemungkinan menerima opini audit going concern. Oleh sebab itu, pada pengujian ini tidak kondusif terhadap teori yang mengatakan jika suatu perusahaan lebih banyak menutupi hutangnya dengan aset lancar yang dimiliki. Sehingga dalam penelitian ini, likuiditas dari suatu perusahaan tidak menjadi penentu bagi auditor untuk mengeluarkan opini auditnya. Penelitian ini sejalan dengan temuan Muttaqin \& Sudarno (2012) membuktikan pernyataan yaitu rasio lancar tidak memberi pengaruh positif terhadap pendapat auditor mengenai kelangsungan hidup entitas begitu juga dalam penelitian Melania et al., (2016); Utami et al., (2017).

Dari uji riset terhadap rasio profitabilitas, $\mathrm{H} 2$ ditolak karena rasio profitabilitas berpengaruh negatif terhadap penerimaan opini audit going concern, dimana nilai signifikannya lebih besar dari tingkat signifikansi yaitu 0,618>0,05. Dalam kondisi tersebut profitabilitas menggambarkan seberapa besar tingkat kenaikan laba perusahaan dan meningkatkan penjualan perusahaan dengan kondisi pesaing baru yang semakin banyak. Dengan jumlah laba dan penjualan yang semakin meningkat akan menunjukkan suatu perusahaan sanggup melanjutkan kelangsungan hidup secara efektif dan tidak menerima opini audit going concern. Tetapi hasil pengujian ini tidak mendukung teori yang dikemukakan tersebut, pemberian opini audit going concern oleh auditor terhadap laporan keuangan suatu perusahaan yang diauditnya tidak dipengaruhi oleh kenaikan laba dan penjualan. Begitu juga dengan penelitian Alamanda (2015; Kusumawardhani (2018); Gusti \& Yudowati (2018) menyatakan rasio profitabilitas tidak memberi pengaruh yang 
positif dikarenakan rasio yang rendah bukan berarti buruk.

Dari uji terhadap variabel rasio leverage, $\mathrm{H} 3$ diterima sebab memberi pengaruh positif terhadap penerimaan opini audit going concern, dimana nilai tingkat signifikansinya lebih besar dari nilai signifikan yaitu $0,05>0,001$.Kondisi perusahaan yang memilki rasio leverage tinggi, dimana pembiayaan hutang dialihkan penuh kebagian ekuitas yang memungkinkan perusahaan tidak bisa menjalankan kelangsungan perusahaan walaupun sudah membentuk rencana dan cara memperbaiki penanggulangan pembayaran hutang jangka panjang untuk meningkatkan operasional perusahaan tetapi tetap menerima opini audit going concern. Oleh sebab itu, rasio leverage sangat memberi pengaruh besar kepada emiten dalam penerimaan opini audit going concern dari auditor.

Dari hasil pengujian yang dilakukan rasio aktivitas, H4 ditolak sebab rasio aktivitas berpengaruh negatif terhadap penerimaan opini audit going concern, dimana nilai signifikannya lebih besar dari tingkat signifikansi yaitu 0,622>0,05. Sejalan dengan hasil temuan (Utami et al., 2017). Dalam keadaan tersebut total aset perusahaan ditentukan oleh seberapa besar pendapatan perusahaan atas penjualannya. Pada umumnya perusahaan manufaktur juga akan mengalami kondisi fluktuasi, dimana total aktivanya dapat mengalami penurunan sehingga memungkinkan suatu perusahaan menerima opini audit going concern. Tetapi berbanding terbalik dengan hasil riset ini, dimana suatu perusahaan tidak menerima opini audit going concern atas laporan keuangan yang telah diaudit walaupun total aktiva suatu perusahaan kecil.

Dari hasil pengujian audit lag, H5 ditolak sebab audit lag berpengaruh negatif 
terhadap penerimaan opini audit going concern, hal ini disebabkan nilai tingkat signifikansi audit lag lebih kecil dari nilai signifikannya yaitu $0,05<1,000$. Hasil penelitian ini sejalan dengan Salean \& Zaroni (2013). Perusahaan mempunyai kewajiban dalam melaporkan laporan keuangan sesuai dengan ketentuan waktu yang ditetapkan. Dimana dalam audit lag perusahaan berkemungkinan untuk menerima opini audit going concern jika melaporkan report financial terlambat. Namun, dalam riset ini tidak kondusif terhadap teorinya karena meskipun laporan keuangan dilaporkan tepat waktu maupun terlambat tidak memiliki pengaruh bagi perusahaan.

Dari hasil pengujian audit client tenure, H6 diterima karena audit client tenure memberi pengaruh positif terhadap penerimaan opini audit going concern, dimana nilai tingkat signifikansinya lebih besar dari nilai signifikan yaitu 0,05>0,000. Lamanya hubungan KAP dan perusahaan bisa memberi pengaruh terhadap perusahaan untuk menerima opini audit going concern. Perikatan antara KAP dan perusahaan memiliki batas waktu yang ditentukan dimana hal ini juga ditekankan dalam peraturan undang-undang kementerian keuangan. Lamanya waktu perikatan antara KAP dan perusahaan tidak mengurangi indenpendensi seorang auditor untuk mengeluarkan pendapat. Dengan demikian, besar perkiraan peluang perusahaan dalam menerima opini audit going concern. Hasil penelitian ini juga sejalan dengan penelitian Dewayanto (2011).

Pada uji terhadap variabel opinion shopping, $\mathrm{H} 7$ diterima sebab variabel tersebut berpengaruh positif terhadap penerimaan opini audit going concern, dimana nilai tingkat signifikansinya lebih besar dari nilai signifikan yaitu 
0,05>0,000. Temuan ini sejalan dengan Putra \& Arisman (2017), dalam hal ini opinion shopping berkaitan dengan auditor, sehingga dalam hal ini perlu juga diperhatikan jangka waktu perikatan antara auditor dan perusahaan dan perikatan tersebut memiliki batas waktu tertentu yang sudah ditetapkan. Perusahaan yang berkemungkinan besar menerima opini audit going concern adalah perusahaan yang malakukan pergantian auditor, karena jangka waktu perikatan antara kedua pihak singkat maka tidak dapat mempengaruhi pendapat auditor dalam mengeluarkan opini audit. Dalam teori juga dikatakan jika suatu emiten tidak mengadakan pertukaran auditor peluang tidak menerima opini audit going concern semakin besar. Tetapi dalam penelitian ini dapat disimpulkan bahwa suatau preusahaan mengganti atau tidaknya seorang auditor tidak mempengaruhi penerimaan opini audit going concern karena hasil penelitian menunjukkan bahwa opinion shopping berpengaruh positif terhadap penerimaan opini audit going concern.

Dari hasil pengujian reputasi KAP, H8 diterima karena memberi pengaruh positif terhadap penerimaan opini audit going concern, dimana nilai signifikannya lebih kecil dari tingkat signifikansi yaitu $0,044<0,05$. Demikian juga hasil temuan Krissindiastuti \& Rasmini (2016). Dalam keadaan tersebut, penggunaan KAP yang besar seperti big four tidak mempengaruhi suatu perusahaan dalam menerima atau tidaknya opini audit going concern. Karena pemberian opini audit going concern kepada suatu perusahaaan itu didasarkan atas report financial perusahaan yang diaudit, seberapa wajarkah posisi keuangan yang disajikan oleh perusahaan tersebut. Sehingga dari hasil ini tidak membenarkan teori bahwa status KAP yang 
semakin bagus, maka semakin besar juga kemungkinan untuk mengeluarkan opini audit going concern demikian kebalikannya karena penerimaan opini audit going concern salah satunya dipengaruhi oleh auditor yang bertanggung jawab dalam mengaudit suatu perusahaan.

\section{SIMPULAN DAN SARAN}

Dari riset yang sudah diuji melalui variabel rasio keuangan dan faktor non keuangan terhadap 163 populasi preusahaan manufaktur yang listing di BEI, sebanyak 60 perusahaan sebagai sampel, dimana sebanyak 68 perusahaan yang menerima opini audit going concern dan sebanyak 99 perusahaan yang tidak menerima opini audit going concern. Hasil yang diperoleh dari pengujian hipotesis adalah rasio leverage diproksikan DER, audit client tenure, opinion shopping dan reputasi KAP berpengaruh positif terhadap penerimaan opini audit going concern yang memperkuat penjelasan kriteria untuk penerimaan opini audit going concern yang dapat diartikan jika perusahaan memiliki masalah dalam mengatur keseimbangan pembiayaan utang melalui ekuitas (rasio leverage) diikuti dengan seberapa sering perusahaan mengganti auditor eksternal maupun KAP sendiri tidak memberikan hasil yang diharapkan perusahaan karena tidak adanya perikatan yang terjalin sehingga objektivitas seorang auditor tetap terjaga.dengan ini kriteria dapat disimpulkan bahwa memungkinkan untuk menerima opini audit going concernakan tetapi audit lag, likuiditas diproksikan CAR, profitabilitas diproksikan ROA, rasio aktivitas diproksikan TATO berpengaruh negatif terhadap penerimaan opini audit going concern yang memperlemah penjelasan kriteria untuk penerimaan opini 
audit going concernyang dapat diartikan rentang waktu penyelesaian pekerjaan lapangan dengan hasil audit tidak memiliki pengaruh untuk penerimaan opini audit going concern diikuti dengan perusahaan mampu menjaga keseimbangan antara aset lancar dengan pendapatan serta laba perusahaan yang terus meningkat menjadikan kondisi keuangan perusahaan stabil dengan demikian kriteria ini tidak memungkinkan perusahaan menerima opini audit going concern.

Adapun keterbatasan dari penelitian ini yaitu : (1) Riset hanya meneliti perusahaan manufaktur yang listing di BEI, tidak terhadap keseluruhaan perusahaan. (2) Dari keseluruhan perusahaan manufaktur hanya 60 sampel perusahaan yang di teliti dan dalam jangka waktu 3 tahun.Dari seluruh pengujian dan kajian yang telah dilaksanakan dan juga kekurangan dalam riset ini, sehingga peneliti mampu memberikan saran berikut ini : (1) Bagi peneliti berikutnya disarankan supaya mampu melakukan penelitian terhadap seluruh perusahaan yang listing di BEI. (2) Peneliti berikutnya juga disarankan untuk menaikkan interval waktu pengamatan terhadap penelitian yang akan dilakukan. (3) Untuk penelitian berikutnya diharapkan untuk menambah variabel rasio keuangan dan faktor keuangan yang lain atau mengubah beberapa proksi yang ada di penelitian sekarang dengan proksi yang lebih baik sehingga dihasilkan penelitian yang lebih baik dan tepat serta mendapatkan nilai signifikan yang semakin baik lagi. Hal tersebut disarankan peneliti sebab jika hanya meneliti variabel yang sudah sering di uji tidak akan menambah dan juga menemukan variabel yang baru yang dapat membantu pengguna informasi ini untuk mendapatkan kriteria yang tepat dalam mendeteksi terjadinya penerimaan opini audit going concern. 


\section{REFERENSI}

Alamanda, P. K. (2015). Pengaruh Ukuran Perusahaan, Profitabilitas, Solvabilitas, dan Debt Default Terhadap Penerimaan Opini Audit Going Concern Pada Perusahaan Manufaktur yang Terdaftar Di Bursa Efek Indonesia (BEI) Periode 2009-2013. Jurnal Akuntansi UNESA, 3(2), 1-24.

Anggelina, D. A., Nurbaiti, A., \& Si, M. (2018). PENGARUH OPINION SHOPPING , UKURAN PERUSAHAAN , DEBT DEFAULT , DAN OPINI AUDIT TAHUN SEBELUMNYA TERHADAP PENERIMAAN OPINI AUDIT GOING CONCERN OPINION OF THE PREVIOUS YEAR TO THE ACCEPTANCE OF AUDIT OPINION GOING ( Study On Mining Companies On Indonesia St. E-Proceeding of Management, 5(3), 3514-3520.

Dewayanto, T. (2011). Analisis Faktor-Faktor Yang Mempengaruhi Penerimaan Opini Audit Going Concern Pada Perusahaan Manufaktur Yang Terdaftar di Bursa Efek Indonesia. Fokus Ekonomi, 6(1), 81-104.

Dewi, M. W., \& Kusuma, I. L. (2018). PENGARUH AUDITOR CLIENT TENURE, UKURAN PERUSAHAAN, PERTUMBUHAN PERUSAHAAN DAN REPUTASI AUDITOR TERHADAP OPINI AUDIT GOING CONCERN. Jurnal Akuntansi Fakultas Ekonomi Dan Bisnis, 7(3), 227-237. https://doi.org/10.21538/0134-4889-2017-23-4-257264

Florentina, M. N. (2016). PENGARUH AUDIT TENURE, DISCLOSURE, REPUTASI AUDITOR, OPINI AUDIT TAHUN SEBELUMNYA, DAN UKURAN PERUSAHAAN TERHADAP PENERIMAAN OPINI AUDIT “GOING GONCERN. ”(Skripsi). Surabaya: STIE Perbanas Surabaya

Ghozali, I. (2016). Aplikasi Analisis Multivariete Dengan Program IBM SPSS 23. Semarang:Badan Penerbit Universitas Diponegoro.

Gusti, Q.R. \& Yudowati, S.P. (2018). PENGARUH LEVERAGE, PROFITABILITAS, PERTUMBUHAN PERUSAHAAN, DAN OPINI AUDIT TAHUN SEBELUMNYA TERHADAP PENERIMAAN OPINI AUDIT GOING CONCERN (Studi Pada Perusahaan Pertambangan yang Terdaftar di Bursa Efek Indonesia Tahun 2013-2016). E-Proceeding of Management, 5(3), 3463-3472.

Herawati, \& Hendra, F. S. (2015). Pengaruh Disclosure Level, Leverage Ratio, dan Debt Default Terhadap Penerimaaan Opini Audit Going Concern Pada Perusahaan Manufaktur. Jurnal Akuntansi, 15(2), 57-69.

Hery, S. . (2013). 240 Konsep Penting Akuntansi Dan Auditing Yang Perlu Anda 
Ketahui. Yogyakarta:Gava Media.

Indrastiti, N. (2016). BEI kaji kembali penilaian going concern emiten. Www.Investasi.Kontan.Co.Id. https://investasi.kontan.co.id/news/bei-kajikembali-penilaian-going-concern-emiten

Kartika, A. (2012). Pengaruh Kondisi Keuangan dan Non- Keuangan Terhadap Penerimaan Opini Going Concern Pada Perusahaan Manufaktur Di BEI. Dinamika Akuntansi, Keuangan Dan Perbankan, 1(1), 25-40.

Krissindiastuti, M., \& Rasmini, N. K. R. (2016). FAKTOR-FAKTOR YANG MEMPENGARUHI OPINI AUDIT GOING CONCERN. E-Jurnal Akuntansi Universitas Udayana, 14(1), 451-481.

Kusumawardhani, I. (2018). Pengaruh Kondisi Keuangan, Financial Distres, Profitabilitas Dan Ukuran Perusahaan Terhadap Opini Audit Going Concern. Buletin Ekonomi, 16(1), 1-136.

Laporan Keuangan dan Tahunan. (2019). Www.Idx.Co.Id. https://www.idx.co.id/perusahaan-tercatat/laporan-keuangan-dan-tahunan/

Melania, S., Andini, R., \& Arifati, R. (2016). Analisis Pengaruh Kualitas Auditor, Likuiditas, Profitabilitas, Solvabilitas Dan Ukuran Perusahaan Terhadap Opini Audit Going Concern Pada Perusahan Manufaktur Yang Terdaftar Di Bursa Efek Indonesia. Journal Of Accounting, 2(2), 1-13.

Muttaqin, A. N., \& Sudarno. (2012). ANALISIS PENGARUH RASIO KEUANGAN DAN FAKTOR NON KEUANGAN TERHADAP PENERIMAAN OPINI AUDIT GOING CONCERN (Studi Empiris Pada Perusahaan Manufaktur di BEI tahun 2008-2010). Diponegoro Journal of Accounting, 1(2), 1-13.

Nainggolan, P. (2016). Analisis Pengaruh Audit Tenure, Ukuran Perusahaan, Opini Audit Tahun Sebelumnya, Kualitas Audit Terhadap Penerimaan Opini Audit Going Concern Pada Perusahaan Manufaktur. Lentera Akuntansi, 2(2), 80-100.

Praptitorini, M. D., \& Januarti, I. (2011). ANALISIS PENGARUH KUALITAS AUDIT, DEBT DEFAULT DAN OPINION SHOPPING TERHADAP PENERIMAAN OPINI GOING CONCERN. Jurnal Akuntansi Dan Keuangan Indonesia, 8(1), 78-93. https://doi.org/10.21002/jaki.2011.05

Putra, I. M., \& Arisman, A. (2017). PENGARUH KUALITAS AUDIT , LIKUIDITAS , PROFITABILITAS , DAN OPINION SHOPPING TERHADAP PENERIMAAN OPINI AUDIT GOING CONCERN ( Studi Empiris Pada Perusahaan Sektor Pertambangan Yang Terdaftar Di Bursa 
Efek Indonesia Tahun 2013-2017 ). Jurnal STIE MDP, O(0), 1-16.

Putri, I. D. sari, \& Primasari, N. H. (2016). Pengaruh Reputasi Auditor, Total Aset, Audit Tenure, dan Komite Audit Terhadap Opini Audit Going Concern (Studi Empiris Pada Perusahaan Manufaktur Sektor Aneka Industri yang Terdaftar pada BEI Periode 2011-2015). Jurnal Akuntansi Dan Keuangan, 5(1), 1-20. https://doi.org/10.1109/ciced.2018.8592188

Salean, A. P., \& Zaroni. (2013). Pengaruh Model Prediksi Kebangkrutan, Leverage, Audit Lag, Dan Ukuran Perusahaan Terhadap Opini Audit Going Concern. Jurnal ULTIMA Accounting, 5(1), 55-76. https://doi.org/10.31937/akuntansi.v5i1.142

Sari, F. N., Adel, J. F., \& Rambe, P. A. (2016). Pengaruh Kepemilikan Perusahaan, Kualitas Auditor, Debt Default Dan Opinion Shopping Terhadap Opini Audit Going Concern Pada Perusahaan Manufaktur Yang Terdaftar Di Bursa Efek Indonesia (BEI) Tahun 2014-2016. REPOSITORY Umrah, O(0), $1-21$.

Sugiono, A., \& Untung, E. (2016). Panduan Praktis Dasar Analisis Laporan Keuangan. Jakarta:PT.Grasindo.

Sujarweni, V. W. (2017). Analisis Laporan Keuangan Teori, Aplikasi Dan Hasil Penelitian. Yogyakarta: Pustaka Baru Press.

Suryani, L. (2014). PRAKTIK MANAJEMEN LABA, PERTUMBUHAN PERUSAHAAN, PRICE EARNING RATIO, AUDIT REPORT LAG TERKAIT PENERIMAAN OPINI AUDIT GOING CONCERN. E-Jurnal Akuntansi Universitas Udayana, 1(8), 154-170.

Suwardjono. (2016). Teori Akuntansi Perekayasaan Pelaporan Keuangan (Ketiga). Yogyakarta:BPFE.

Tamir, H. I. A., \& Anisykurlillah, I. (2014). PENGARUH KUALITAS AUDIT, KONDISI KEUANGAN, PERTUMBUHAN, KEPEMILIKAN PERUSAHAAN DAN REPUTASI KAP TERHADAP PENERIMAAN OPINI AUDIT GOING CONCERN PADA PERUSAHAAN TEXTILE DAN GARMENT YANG LIST DI BEI TAHUN 2010-2012. Accounting Analysis Journal, 3(4), 437-445.

Tarihoran, D. S. H., \& Budiono, E. (2016). Pengaruh Ukuran Perusahaan, Ukuran Kantor Akuntan Publik, Dan Opinion Shopping Terhadap Penerimaan Opini Audit Going Concern. E-Proceeding of Management, 3(1), 313-319.

Utami, M. A. J. P., Sari, M. M. R., \& Astika, I. B. P. (2017). KEMAMPUAN PRIOR OPINION MEMODERASI PENGARUH PROFITABILITAS, 
LEVERAGE, LIKUIDITAS, PERTUMBUHAN PERUSAHAAN DAN RASIO AKTIVITAS TERHADAP OPINI AUDIT GOING CONCERN. $E$ Jurnal Ekonomi Dan Bisnis Universitas Udayana, 7(6), 2861-2888. https://doi.org/10.24843/eeb.2017.v06.i07.p09

Wareza, M. (2019). 3 Emiten akan Delisting, Ada Apa?. https://www.cnbcindonesia.com/market/20190909125031-17-98023/3emiten-akan-delisting-ada-apa

Wendy, I., Rizal, V., \& Hantono, H. (2019). Faktor yang Mempengaruhi Audit Delay pada Industri Dasar dan Kimia. Berkala Akuntansi Dan Keuangan Indonesia, 4(1), 35-48. https://doi.org/10.20473/baki.v4i1.11816

Wibisono, E. A. (2013). PREDIKSI KEBANGKRUTAN, LEVERAGE, AUDIT SEBELUMNYA, UKURAN PERUSAHAAN TERHADAP OPINI GOING CONCERN PERUSAHAAN MANUFAKTUR BEI. Jurnal EMBA, 1(4), 362-373. 